\title{
O ESTADO LAICO SEGUNDO O SUPREMO TRIBUNAL FEDERAL: ASPECTOS DA LEGALIDADE OBLÍQUA E CONTRAMAJORITÁRIA NO BRASIL
}

\section{THE SECULAR STATE ACCORDING TO THE BRAZILIAN SUPREME FEDERAL COURT: ASPECTS OF OBLIQUE AND CONTRAMAJORITARIAN LEGALITY}

Bruno Galindo*

\section{RESUMO}

O presente ensaio pretende debater a leitura das dimensões do Estado laico no Brasil que o Supremo Tribunal Federal tem feito em sua jurisprudência. A hipótese central é a de que ao menos nesse particular, a Suprema Corte brasileira tem construído uma legalidade oblíqua e contramajoritária como uma espécie de rule of law de defesa dos direitos de segmentos vulneráveis da população, por vezes atingidos quando levadas adiante concepções religiosas hegemônicas. As decisões analisadas, envolvendo principalmente embates entre ciência e religião e a oposição de segmentos religiosos a direitos da população LGBTQIA+ permitem a verificação da hipótese no desenvolvimento das teses nelas prevalentes e se a dita legalidade oblíqua e contramajoritária realmente está presente na concepção jurisprudencial dominante na Corte sobre o Estado laico.

PALAVRAS-CHAVE: STF; Estado laico; rule of law; legalidade; contramajoritariedade; religião; LGBTQIA+.

\section{ABSTRACT}

This essay intends to discuss the reading of the dimensions of the secular state in Brazil that the Federal Supreme Court has made in its jurisprudence. The central hypothesis is that, at least in this regard, the Brazilian Supreme Court has constructed an oblique and counter-majoritarian legality as a kind of rule of law to defend the rights of vulnerable people, sometimes affected when hegemonic religious conceptions are carried out. The analyzed decisions, mainly involving clashes between science and religion and the opposition of hegemonic religions to the rights of the LGBTQIA+ population, enable to verify the hypothesis in the development of the prevailing theses in them and if the so-called oblique and counter-majoritarian legality is really present in the dominant jurisprudential conception in the Court about the secular state.

KEYWORDS: STF; secular state; rule of law; legality; counter-majority; religion; LGBTQIA+.

"Os homens nunca fazem o mal tão completa e entusiasticamente como quando o fazem por convicção religiosa.” (Eco: 2011, p. 21)

\section{INTRODUÇÃO: MINORIAS ${ }^{1}$ E PAPEL CONTRAMAJORITÁRIO DO PODER}

\footnotetext{
* Professor Associado da Faculdade de Direito do Recife/Universidade Federal de Pernambuco (UFPE); Doutor em Direito pela UFPE/Universidade de Coimbra-Portugal (PDEE); e-mails: bruno.tgalindo@ufpe.br; brunogalindoufpe@gmail.com.

${ }^{1}$ Embora não ignoremos que os segmentos vulneráveis da população possam ser em alguns casos até maioria, caso das mulheres em geral e das pessoas negras em muitos países, consideramos aqui como minorias para efeito de compreensão do papel contramajoritário da legalidade oblíqua promovida pelo poder judiciário, em especial cortes
} 


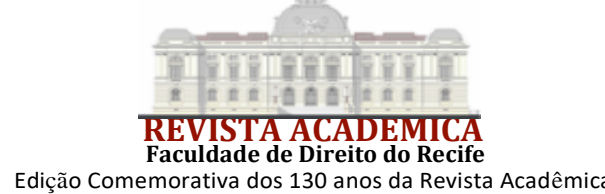

\section{JUDICIÁRIO}

$\mathrm{Na}$ feliz oportunidade de escrever para essa edição comemorativa referente aos 130 anos da Revista Acadêmica da Faculdade de Direito do Recife/UFPE, instituição da qual tenho imenso orgulho de ser docente há 15 anos, resolvi esboçar algumas reflexões sobre as relações entre Estado laico e poder judiciário, em especial o STF, verificando a hipótese de estarmos edificando uma legalidade oblíqua e contramajoritária no Brasil como parte integrante e fundamental do Estado democrático de direito.

É bem sabido que democracia enquanto regime político é essencialmente caracterizada como "governo do povo", pelo menos desde a Grécia antiga (Atenas), na junção dos vocábulos demos e kratos. O "povo", diretamente ou por meio de seus representantes (aqui já na era moderna), exerce o poder político em um Estado democrático.

Nesses contextos, as deliberações políticas legislativas são comumente atribuídas aos representantes do povo que, por maioria, decidirão em nome deste o que deve ser obrigatório, permitido e proibido em termos de legislação geral dirigida à população e aos poderes públicos.

Contudo, para que a democracia majoritária não se torne uma "tirania da maioria", é comum nas democracias a estipulação constitucional de direitos fundamentais de segmentos sociais minoritários, precisamente para que as maiorias não se tornem opressivas impondo às minorias de modo coercitivo suas concepções ideológicas, morais e religiosas. Diante da ocasional impossibilidade dos parlamentos, casas majoritárias, de resguardarem com eficiência os direitos das minorias, o poder judiciário pode ser o catalisador da defesa desses direitos, notadamente por sua condição de poder eventualmente contramajoritário, pois na maioria das democracias é um poder que não tem o dever imediato de dar satisfações às maiorias.

A partir de tal constatação, para muitos estaríamos ante o fenômeno do ativismo judicial, especialmente quando o poder judiciário, no exercício do controle da constitucionalidade das leis e diante de ações e omissões legislativas inconstitucionais, se coloca em aparente confronto com a instituição parlamentar majoritária sob o argumento de defesa da constituição (LIMA, 2014, p. 164 et seq.; VÁSQUEZ, 2010, p. 390 et seq.; VALLE, 2009, p. 39). Particularmente, ante o estigma negativo que o termo ativismo adquiriu, prefiro trabalhar com uma ideia por mim esboçada tempos atrás em um ensaio que é a de legalidade oblíqua e contramajoritária (GALINDO, 2009).

Esse debate é bastante amplo, e neste ensaio não tenho a pretensão de enfrentá-lo em sua plenitude. As pretensões aqui são mais modestas e, em virtude disso, o estudo foi delimitado da seguinte maneira: a legalidade oblíqua a ser estudada será aquela realizada pelo Supremo Tribunal Federal, excluindo, em princípio, investigações sobre decisões de outras cortes e juízos; e do ponto de vista material, a defesa do Estado laico perpetrada por esta Corte, em posicionamentos contrários às pressões políticas de maiorias religiosas no Congresso Nacional. Para o estudo, proponho a bifurcação em dois temas nos quais a concepção de Estado laico é especialmente relevante: 1) o embate ocasional entre ciência e religião, traduzido nas decisões proferidas na ADI 3510 e na ADPF 54, referentes respectivamente às questões das células-tronco embrionárias e da interrupção da gravidez de feto anencéfalo; e 2) os direitos LGBTQIA+ e a oposição de maiorias religiosas a eles, questão que perpassa as decisões nas ADIs 4277 e 4275 e na ADO 26, respectivamente referentes às uniões estáveis homoafetivas, aos direitos de personalidade de pessoas transgênero e à criminalização da LGBTfobia, não sem antes proceder a esclarecimentos conceituais para situar o leitor no atual "estado da arte" da questão.

\section{DEMOCRACIA PARLAMENTAR E DIREITOS DAS MINORIAS: ENTRE A SUPREMACIA DO PODER LEGISLATIVO E O RULE OF LAW}

constitucionais e supremas cortes, como o STF. Em razão disso, utilizaremos o termo "minorias" nessa acepção ampla para os limites deste ensaio. 


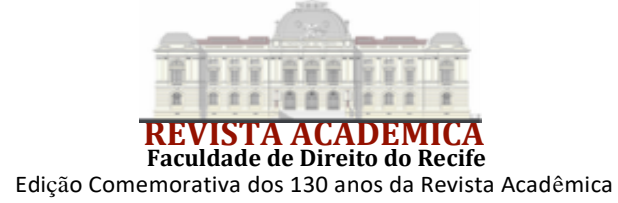

O parlamento é instituição imprescindível a qualquer regime democrático. Sendo representativo das diversas ideologias e visões de mundo dos variados segmentos sociais, tal colegiado de pessoas reflete uma pluralidade existente na própria sociedade democrática. Em que pese a ideia clássica dos gregos da Antiguidade de ver a democracia essencialmente como meio de deliberação direta do próprio povo, ideário acolhido por Rousseau, bem como existente em alguns dos cantões suíços de hoje, o fato é que o modelo de democracia representativa, consubstanciado na eleição para mandatos temporários de representantes da população para exercerem o poder legislativo, se consagrou mundialmente como o modelo por excelência do regime democrático possível, não obstante as inúmeras críticas quanto à sua funcionalidade (ARISTÓTELES, 1998; ROUSSEAU, 1995; BONAVIDES, 2003, p. 201 et seq.).

A democracia representativa funciona a partir da existência de um parlamento cujas prerrogativas típicas são legislar e fiscalizar os demais poderes, inserido em um sistema de freios e contrapesos (checks and balances), com as funções executiva e jurisdicional atribuídas respectivamente aos poderes executivo e judiciário, não obstante a existência de funções atípicas em todos os poderes do Estado.

As revoluções liberais ocorridas a partir do século XVII levaram ao fortalecimento do parlamento como colegiado de representação popular. A profunda desconfiança em relação ao monarca e aos magistrados, servos da monarquia no absolutismo, levou os revolucionários a verem no parlamento, instituição eletiva, plural e com membros legitimados periodicamente pelo sufrágio, o organismo adequado para criar e definir direitos, obrigações e proibições no âmbito de uma sociedade democrática.

Especialmente em países como Reino Unido e França o prestígio político do parlamento alcançou patamares muito elevados.

Na França, a principal Escola jurídica do início do constitucionalismo a orientar os juristas nacionais na interpretação das leis foi a Escola da Exegese. Ao defender um literalismo interpretativo extremado, os partidários de tal corrente de pensamento acabaram por conferir ao poder legislativo a única palavra em termos de criação e interpretação das leis, já que, na aplicação da lei, o juiz deveria simplesmente considerar a literalidade do texto legal, sem espaço para inclusão de elementos históricos, teleológicos ou de outras naturezas, que tanto foram explorados posteriormente pela hermenêutica jurídica clássica e contemporânea (GALINDO, 2009, p. 177; GALINDO, 2006; SIEYÈS, 1997; GARCÍA-PELAYO, 1999, p. 309-310; NEVES, 2001, p. 357; NEVES, 2006, p. 219 et seq.; SALDANHA, 2000, p. 75 et seq.; ADEODATO, 2006, p. 132).

No Reino Unido, a supremacia do parlamento foi erigida ao status de princípio basilar do funcionamento de todo o direito constitucional. Na democracia britânica, a existência, a partir de fins do século XVII, de uma casa parlamentar legitimada diretamente pela própria população através do voto fez com que se sedimentasse ao longo de mais de 3 séculos o princípio da supremacia do parlamento, tendo em vista a ausência de uma constituição codificada, orgânica e rígida dentre eles. Teoricamente não haveria freios à ação do poder legislativo no Reino Unido, podendo o Parlamento de Westminster tanto aprovar leis que criem ou modifiquem as normas sobre saneamento básico e trânsito, como até mesmo transformar a forma de governo de monarquia em república ou abolir as Cartas clássicas de direitos, como a Magna Charta Libertatum (1215) e o Bill of Rights (1689) (GALINDO, 2009, p. 178-179; GALINDO, 2004, p. 308-310; DICEY, 1982).

Contudo, essa aparente ausência de freios ao poder daquele Parlamento não pode ser compreendida adequadamente se desconsiderarmos outro elemento, tão importante quanto a supremacia do Parlamento, para a compreensão do funcionamento do constitucionalismo britânico. Refiro-me ao rule of law, ideia antiga e bastante prestigiada no sistema jurídico conhecido como common law.

Expressão típica do direito britânico, rule of law possui significado aproximado com a ideia de domínio do direito ou mesmo de Estado de direito, embora a tradução literal seja "regra de 


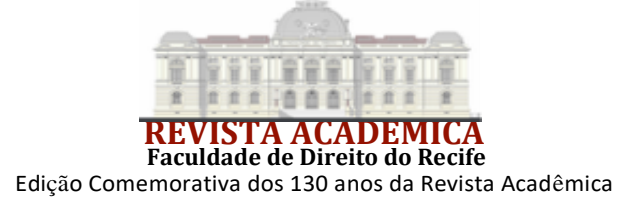

direito" (SANTORO, 2006, p. 214-215). Não obstante, é preferível utilizar a expressão em inglês, tendo em vista que não há um correlato específico em português, além de ser uma ideia muito específica daquele constitucionalismo.

Em verdade, apesar de sempre fazerem referência ao rule of law, os juristas britânicos pouco se preocuparam em defini-lo. Somente no final do século XIX, a obra paradigmática de Albert Venn Dicey teve a preocupação de esclarecer tal conceito, considerado por este último autor como eixo central do direito britânico, talvez mesmo mais importante que a própria "supremacia do parlamento" (SANTORO, 2006, p. 214-215; DICEY, 1982, p. 268 et seq.; JOWELL, 2004, p. 68).

Tendo em vista o caráter inorgânico e assistemático da Constituição do Reino Unido, já que a mesma é composta por atos legislativos (statute law) e jurisprudenciais (common law stricto sensu), além das convenções constitucionais (constitutional conventions - única parte efetivamente consuetudinária da referida constituição), torna-se necessário salvaguardar os direitos e liberdades dos britânicos, não somente diante do monarca e dos juízes, mas também diante do próprio parlamento "soberano". Inseridos no contexto do rule of law britânico estariam os limites ao poder discricionário do Estado, a exclusão da arbitrariedade no trato com a coisa pública, a isonomia entre os cidadãos do Reino, o devido processo legal, o direito a um julgamento justo com contraditório e ampla defesa, a segurança jurídica, a igualdade perante a lei, enfim, uma série de garantias e direitos fundamentais que servem como norteadores da atuação das cortes e do próprio Parlamento para que o direito como um todo prevaleça (a "supremacia do direito") (JOWELL, 2004; DICEY, 1982; GALINDO, 2004).

A ideia central no constitucionalismo britânico, portanto, é que tais garantias e direitos substantivos sejam assegurados legislativa, administrativa ou jurisprudencialmente. Pouco importaria a origem da norma em questão, bastando que a mesma observe o rule of law.

$\mathrm{O}$ rule of law termina por se tornar um contraponto importante à supremacia parlamentar, sobretudo em momentos nos quais esta prevalência aparentemente democrática possa se tornar uma espécie de "tirania" ou "ditadura" da maioria. A democracia não subsiste sem um mínimo de direitos humanos/fundamentais, da mesma forma que estes não são prevalentes em um regime autoritário. O binômio democracia-direitos humanos é fundamental ao constitucionalismo, não obstante as variações conceituais e práticas que tais expressões possam ter (GALINDO, 2006, p. 144). E o rule of law como eventual instrumento contramajoritário é especialmente relevante quando tratamos de direitos fundamentais de minorias, sejam elas étnicas, ideológicas, religiosas ou de qualquer outra natureza.

Em tal contexto, tribunais constitucionais e cortes supremas, a exemplo do STF brasileiro, terminam por assumir esse papel concretizador do rule of law, ainda que contramajoritariamente, o que acarreta discussões acerca da legitimidade dessas cortes para essa tarefa, bem como dos problemas de politização do próprio órgão judiciário que, não diferentemente do ocorrente com o parlamento, também se encontra com frequência pressionado social e politicamente (para não dizer economicamente) quanto aos fundamentos e consequências de suas decisões.

\section{SUPREMO TRIBUNAL FEDERAL E A CONSTRUÇÃO DE UMA LEGALIDADE OBLÍQUA E CONTRAMAJORITÁRIA}

A ideia de um rule of law, que talvez possa ser aproximada ao ideário do Estado de direito no âmbito do sistema romanista, pode justificar e fundamentar a construção daquilo que em outra oportunidade denominei de "legalidade oblíqua". Na ocasião, debatendo as novas possibilidades e limites do princípio da legalidade, defendi a aproximação entre a ideia principiológica de legalidade no Estado de direito do sistema romanista com a prevalência do rule of law no sistema jurídico anglo-americano (common law).

Ainda naquele ensaio em que discutia os reflexos dessa percepção no debate sobre a súmula

GALINDO, Bruno. O ESTADO LAICO SEGUNDO O SUPREMO TRIBUNAL FEDERAL: ASPECTOS DA LEGALIDADE OBLÍQUA E CONTRAMAJORITÁRIA NO BRASIL. Revista Acadêmica da Faculdade de Direito do Recife - ISSN: 24482307, Edição Comemorativa dos 130 anos da Revista Acadêmica, p. 56-79. Nov. 2021. ISSN 2448-2307. <Disponível em: 


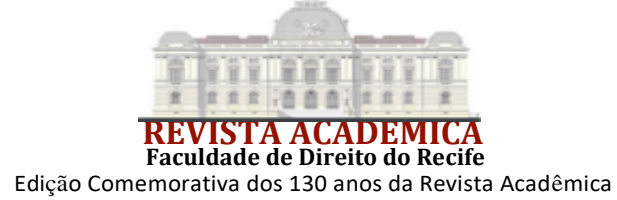

vinculante então incipiente em nosso constitucionalismo, destaquei que o considerável aumento da importância da atuação da jurisdição constitucional no Brasil, em especial do STF, poderia ensejar o advento de uma legalidade oblíqua como uma espécie de rule of law brasileiro. Tal perspectiva afastar-se-ia de um princípio da estrita legalidade (exigência de lei formal ou ato legislativo do poder legislativo) e aceitaria esse rule of law com a presença de atos de natureza legislativa tanto provenientes do próprio legislativo como dos demais poderes do Estado (GALINDO, 2009, p. 178-179).

Direcionando o argumento da legalidade oblíqua ao tema deste ensaio, pode-se afirmar que essa percepção do princípio da legalidade depende da compreensão do papel contramajoritário que pode ser exercido pelas cortes supremas e/ou tribunais constitucionais, em especial a partir de suas posturas muitas vezes consideradas ativistas, embora não haja uma relação necessária entre ativismo e contramajoritariedade.

Em princípio, a legalidade oblíqua seria associada a uma perspectiva ativista da atuação da jurisdição constitucional, sendo o ativismo aqui entendido correntemente como uma postura judicial invasiva da esfera de competência dos outros poderes estatais, independentemente da percepção axiológica em torno dos benefícios e dos malefícios de tal intervenção.

De plano, desejo afastar qualquer percepção entusiasta ou pejorativa do termo "ativismo", priorizando seu aspecto analítico. Sendo assim, uma corte ativista pode ser progressista ou conservadora, de "direita" ou de "esquerda", liberal ou social, muito embora o termo "ativismo judicial" seja mais comumente associado às cortes norte-americanas de viés liberal. ${ }^{2}$ Na história da Suprema Corte norte-americana, alternaram-se os colegiados entre posturas ativistas e autolimitativas (self restraint) (KRAMER, 2004, p. 219 et seq.; LIMA, 2014).

O termo "ativismo" surgiu em um artigo do jornalista norte-americano Arthur Schlesinger Jr. em que analisava o perfil dos juízes da Suprema Corte dos EUA em 1947, constatando que dos nove, quatro seriam ativistas, três seriam defensores da autolimitação e dois estariam em uma postura intermediária. Posteriormente, puderam ser descritas como ativistas tanto a liberal e paradigmática Corte Warren dos anos 50/60 do século passado, como a conservadora Corte Rehnquist dos anos 80/90 (VALLE, 2009, p. 20; LIMA, 2014, p. 164 et seq.).

Diferentemente do que ocorre nos EUA onde se pode falar em uma Suprema Corte ativista pelo menos desde o leading case Marbury x Madison (1803), cuja atuação do Chief Justice John Marshall se tornou emblemática nesse sentido (cf. BARNETT, 2004, p. 143-147; TRIBE, 2000, p. 207-213), no Brasil tal fenômeno só vem a ocorrer com algum destaque no desenvolvimento da jurisdição constitucional pós-Carta de 1988, especialmente no controle concentrado de constitucionalidade exercido pelo STF.

De atuação mais próxima do self restraint nos primeiros anos de vigência da Constituição de 1988, a Corte suprema brasileira passa a uma postura bem mais ativista a partir da primeira década deste século, tendo enfrentado temas polêmicos e de alcance social bastante abrangente (MENDES, 2011, p. 67). Exercendo um papel legislativo negativo e até positivo, o STF tem decidido tais questões sem considerar tão estritamente a clássica "separação de poderes", construindo o que denominei de legalidade oblíqua (GALINDO, 2009). Esta poderia ser compreendida como a construção de um rule of law brasileira a partir de diversas fontes do direito, não somente aquelas produzidas pelo poder legislativo.

Esclarecerei melhor adiante no estudo da questão do Estado laico, cujos exemplos abordados demonstram essa atuação do STF na construção de uma legalidade oblíqua, embora os graus e dimensões desta variem em torno das decisões analisadas.

\footnotetext{
${ }^{2}$ É importante considerar que, no contexto norte-americano, o termo "liberal" não possui a mais dimensão que em outros lugares. Nos EUA pode-se falar em liberais x conservadores principalmente a partir de ideias associadas ao liberalismo político e não necessariamente ao econômico (RAWLS, 2004).
} 


\section{DIREITOS FUNDAMENTAIS NO ESTADO LAICO: O AFASTAMENTO DE CONCEPÇÕES ESTRITAMENTE RELIGIOSAS NA FUNDAMENTAÇÃO DE AÇÕES DO ESTADO}

A análise de uma eventual atuação ativista do STF - cabe aqui o alerta - não deve conduzir a uma defesa da expansão irrestrita da jurisdição constitucional deste ou de outros tribunais, sejam cortes supremas e/ou constitucionais. Retomando o argumento final do item 1 e considerando a ponderação de Bayon, os juízes constitucionais, tal como os parlamentares, estão suscetíveis a todo tipo de pressão social, política e econômica e, não raro, decidem a partir de formação negociada de compromissos e se utilizando do critério majoritário no âmbito interno (BAYON, 2010, p. $322-$ 323). A composição colegiada de tais cortes também tende a refletir, em especial nos tribunais constitucionais, a pluralidade ideológica existente na sociedade e, inúmeras vezes, é perceptível a defesa de determinados posicionamentos judiciais nessas cortes a partir das ideologias e/ou visões de mundo (aí incluídas as religiosas) presentes na sociedade. ${ }^{3}$

O parlamento é, sem dúvida, a casa mais plural, representativa e legítima para que debates envolvendo direitos fundamentais sejam desenvolvidos e recebam desse colegiado soluções legislativas adequadas. Porém, seja por omissão, seja por ação, decisões franca ou veladamente discriminatórias em relação a direitos fundamentais ocorrem com certa frequência no âmbito das casas legislativas. Nem sempre as maiorias parlamentares são o melhor veículo para a proteção de direitos fundamentais, tendo em vista os próprios interesses - diga-se de passagem, legítimos - em suas reeleições ou projeções eleitorais para cargos políticos diversos. Este fator pode condicionar a atuação de muitos parlamentares a se posicionarem ao lado de uma maioria popular em contraposição a uma minoria que veria os seus direitos desprotegidos em função de tal situação (BAYON, 2010, p. 320; DWORKIN, 1999, p. 372-375; ACKERMAN, 2009, p. 108-109; DIAS, 2008, p. 142). Nesta, a jurisdição constitucional, considerando a desnecessidade de uma prestação de contas política diretamente feita à população, possui, em muitos momentos, melhores condições de resguardar os direitos fundamentais de minorias, ainda que enfrentando as maiorias contrárias a esta proteção. ${ }^{4} \mathrm{O}$ fato de que os membros dessas cortes não precisam se submeter ao sufrágio universal para lá estarem ou se manterem facilita decisões mais equânimes em razão dos custos eleitorais e políticos que decisões sobre temas polêmicos tomadas pelo poder legislativo podem acarretar em relação aos seus membros. Daí a postura por vezes omissiva do legislador, deixando tais problemas insolúveis e, no vácuo político, permitindo, quiçá até incentivando, uma judicialização da questão, transferindo o ônus político-eleitoral para os juízes constitucionais.

Os problemas referentes aos direitos fundamentais decorrentes da laicidade como princípio do Estado democrático são bastante elucidativos sobre essa atuação do STF. Na timidez das ações ou mesmo nas omissões do Congresso Nacional sobre muitos dos temas que envolvem a questão do Estado laico, o STF tem se utilizado da legalidade oblíqua para tornar mais independentes as ações do Estado que envolvem direitos de minorias rechaçados pelas religiões dominantes.

Não deixa de ser curioso que muitas desses segmentos religiosos que atualmente são dominantes ou possuem uma grande influência a partir de sua organização sistemática e estratégica

${ }^{3}$ Merece referência sobre o perfil ideológico dos Ministros do STF do período 1999-2004 o singular estudo de Ricardo Silveira Ribeiro sobre a política constitucional do STF (RIBEIRO, 2007).

${ }^{4}$ Esclarecedora a posição de Ferrajoli a respeito: "Una Constitución no sirve para representar la voluntad común de un Pueblo, sino para garantizar los derechos de todos, incluso frente a la voluntad popular. Su función no es expressar la existencia de un demos, es decir, de una homogeneidad cultural, identidad colectiva o cohesión social, sino, al contrario, la de garantizar, a través de aquellos derechos, la convivencia pacífica entre sujetos e intereses diversos y virtualmente en conflicto. El fundamento de su legitimidad, a diferencia de lo que ocorre con las leyes ordinarias y las opciones de gobierno, no reside en el consenso de la mayoría, sino en un valor mucho más importante y previo: la igualdad de todos en las libertades fundamentales y en los derechos sociales, o sea en derechos vitales conferidos a todos, como limites y vínculos, precisamente frente a las leyes y los actos de gobierno expressados en las contingentes mayorías." (FERRAJOLI, 2003, p. 28). 


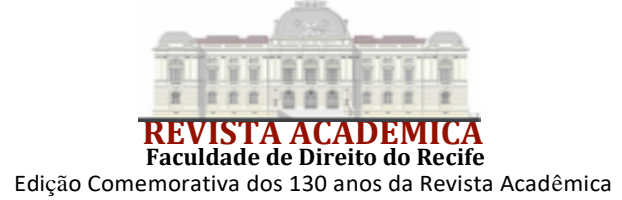

em relação a apoios políticos ou mesmo a candidaturas formais de líderes religiosos (caso dos evangélicos, p. ex., notadamente as igrejas neopentecostais) devem sua própria liberdade religiosa ao Estado laico que, nascido com a República no final do século XIX, permitiu a ascensão da laicidade como princípio constitucional em lugar do Estado confessional católico existente durante o Brasil Império e, com isso, o direito dos cristãos protestantes/evangélicos professarem sua fé em condições de igualdade com os católicos e outras denominações religiosas (MACHADO, 2008).

A laicidade, em verdade, é algo anterior à transição brasileira entre Império e República. Trata-se de um neologismo francês que, não obstante sua inspiração iluminista, surgiu na segunda metade do século XIX no contexto do ideal republicano da liberdade de opinião (aí inserida a liberdade de religião), do reconhecimento e aceitação das diferentes concepções religiosas e da fundação estritamente política do Estado independentemente de suposta vontade divina (ORO, 2008, p. 81).

Pode-se definir a laicidade como "um regime social de convivência, cujas instituições políticas estão legitimadas principalmente pela soberania popular e já não mais por elementos religiosos" (BLANCARTE, 2008, p. 19). Essa transição do religioso ao democrático não necessariamente implica em uma secularização extremada do Estado, mas tende à cooperação entre Estado e religiões, bem como ao respeito às liberdades de culto, de manifestação, de organização, incluindo até incentivos físcais em relação ao funcionamento de templos (CF, art. 150, VI, b).

No entanto, a cooperação e o respeito à liberdade religiosa não conduzem a uma conformação da legislação e das políticas públicas a preceitos de natureza religiosa. A laicidade como princípio pode existir até mesmo em Estados confessionais com Igrejas nacionais e/ou oficiais, casos - p. ex. - da Argentina (católica), da Dinamarca e da Noruega (luterana) e do Reino Unido (anglicana) que, não obstante se afirmarem oficialmente confessionais, possuem formas de legitimação política essencialmente democráticas, adotando políticas públicas com esse viés, alheias à moral da Igreja oficial (BLANCARTE, 2008, p. 20-21).

O princípio da laicidade exige do Estado uma posição equidistante das religiões. Respeitaas e facilita seu exercício, mas não deve assumir como suas determinações com fundamento estritamente religioso, sobretudo se implicarem na diminuição ou supressão de direitos de outrem que não professem aquela religião. Na definição de Huaco, seriam elementos essenciais da laicidade como princípio jurídico:

a) A separação orgânica e de funções, assim como a autonomia administrativa recíproca entre os agrupamentos religiosos e o Estado;

b) $\mathrm{O}$ fundamento secular da legitimidade e dos princípios e valores primordiais do Estado e do Governo;

c) A inspiração secular das normas legais e políticas públicas estatais;

d) A neutralidade, ou imparcialidade frente às diferentes cosmovisões ideológicas, filosóficas e religiosas existentes na sociedade (neutralidade que não significa ausência de valores, mas sim imparcialidade perante as diferentes crenças);

e) A omissão do Estado em manifestações de fé ou convicção ideológica junto aos indivíduos (Huaco: 2008, p. 42 - grifos do autor).

Sendo um tanto mais prosaico: católicos não podem provar a virgindade de Maria; evangélicos/protestantes não podem provar a inspiração divina da Bíblia; cristãos em geral não podem provar a ressurreição de Jesus; judeus não podem provar sua condição de "povo eleito" por Deus; muçulmanos não podem provar que Maomé/Mohammed escreveu no Alcorão somente o que Alah desejava; teístas não podem provar a existência de Deus; ateus não podem provar a inexistência de Deus. Tudo isso são questões dependentes da fé de cada um e da liberdade de consciência e de crença.

Diante da profunda incerteza quanto à correção dos preceitos religiosos de todas essas denominações, o Estado laico surge como um catalisador da liberdade religiosa e do livre-arbítrio, preconizando uma atuação estatal cujos fundamentos estejam na soberania popular democrática e 


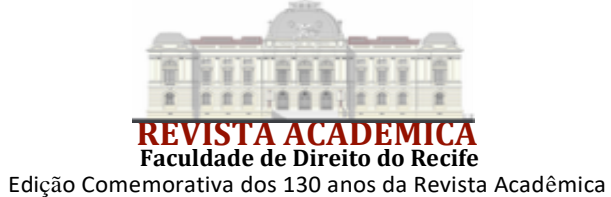

nos direitos humanos/fundamentais de todos os membros da sociedade, quer pertencentes aos segmentos sociais majoritários, quer aos minoritários. A laicidade implica na proteção desses direitos, em última análise, para assegurar a igualdade de condições de exercício das liberdades públicas (FERNÁNDEZ-CORONADO, 2009, p. 152).

O Estado laico, contudo, não é algo consolidado. Não é um dado, mas uma construção. Como afirma Blancarte, "é mais um processo do que uma forma fixa ou acabada em forma definitiva" (BLANCARTE, 2008, p. 20).

Há mais de um século que o Brasil é oficialmente um Estado laico. Todavia, posturas de assédio religioso continuam ocorrendo no espaço público. Lorea destaca em estudo sobre o tema, situações como a de um Secretário de Segurança Pública que "convidava" os seus subordinados a orarem juntamente com ele e um pastor evangélico, ${ }^{5}$ a de uma empresa que obrigava seus funcionários a orarem segundo a orientação religiosa da Igreja do Evangelho Quadrangular à qual uma das sócias era vinculada, a exigência do comparecimento a cultos e eventos religiosos aos professores de algumas escolas confessionais ${ }^{6}$ e um caso de assédio religioso bastante emblemático no Município de Entre-Ijuís, no Rio Grande do Sul, cuja Câmara de Vereadores aprovou lei que determinava a obrigatoriedade da leitura bíblica antes do início das aulas em todas as escolas municipais de ensino fundamental (LOREA, 2008). ${ }^{7}$ Várias assembleias legislativas e câmaras municipais aprovaram leis tornando obrigatória a presença de exemplares da Bíblia em escolas e bibliotecas públicas, leis que em geral têm sido consideradas inconstitucionais pelo STF, a exemplo da Lei 74/2010 do Estado de Amazonas, cuja declaração parcial de inconstitucionalidade foi recentemente feita pelo Corte suprema brasileira (ADI 5258, Rel. Min. Carmem Lúcia, DJe 27/04/2021).

É fato que há muitas tentativas de conformação das políticas públicas e da legislação a preceitos de natureza religiosa. A partir da eleição de mais parlamentares da denominada "Bancada da Bíblia" e do próprio Presidente da República que já defendeu em manifestação pública quando ainda candidato que o Estado brasileiro deveria ser "Estado cristão" e não Estado laico9, essas tentativas aumentaram exponencialmente. Esse tipo de ação política traz inequívocos prejuízos à convivência democrática e ao respeito aos direitos das minorias. Ainda que se tenha convicções religiosas firmes, estas não podem ser impostas ao restante da população. Embora seja algo aparentemente simples, em termos práticos, percebe-se que muitos não entendem dessa maneira. Mas o mais grave é quando obtêm êxito em condicionarem o Estado laico às suas convicções religiosas e morais pessoais. Nessas situações parece faltar uma sedimentação cultural mais forte da laicidade como princípio constitucional.

Roberto Blancarte tece considerações muito relevantes sobre a atuação do Estado laico e seus pressupostos ideológicos e, como são convergentes em relação ao que se defende aqui,

${ }^{5}$ É importante ressaltar que o Estado laico não se confunde com Estado anticlerical ou antirreligioso. Eventual extremismo laico como o caso da utilização pessoal de símbolos religiosos nas escolas francesas não é a regra geral (LOREA, 2008, p. 162; LADEVÉZE, 2007, p. 37et seq.). Basta citar o Caso Ludin, em Baden-Würtenberg, Alemanha, em que uma professora alemã de religião muçulmana teve reconhecido, por decisão do Tribunal Constitucional Federal em setembro de 2003, o seu direito de usar o hyiab (espécie de véu cobrindo os cabelos) em sala de aula como corolário de sua liberdade de religião, não tendo enxergado a Corte alemã qualquer atitude proselitista por parte da docente (cf. MARTÍN VIDA; MÜLLER-GRUNE, 2004). Aliás, o próprio proselitismo religioso, que consiste na tentativa de convencer outrem a abraçar uma crença religiosa, não é ilícito, desde que não configure o aludido "assédio", já tendo sido objeto de decisão do Tribunal Europeu de Direitos Humanos (Kokkinakis x Grécia) (ORTEGA, 2005, p. 329; SABAU, 2005, p. 150).

${ }^{6}$ Sobre problemas especificamente relacionados ao ensino e educação religiosa, vale a pena conferir - Cunha, 2008; Fernández, 2007.

${ }^{7}$ Esta Lei (Lei Municipal no 1525/2006) foi declarada inconstitucional pelo Tribunal de Justiça do Rio Grande do Sul (LOREA, 2008, p. 167).

${ }^{8}$ Denominação referida a parlamentares que se elegeram com discurso e propostas políticas de aberto apelo à religião cristã, por vezes inclusive utilizando-se de "títulos" de natureza religiosa, como pastor, irmão, presbítero, bispo etc.

${ }^{9} \mathrm{Cf}$. https://www.youtube.com/watch?v=YmE4pxBulMw, acesso: 10 nov. 2021. 
merecem transcrição:

\begin{abstract}
Evidentemente, a moral pública não pode estar totalmente secularizada, à medida que as religiões formam parte essencial da cultura dos povos, portanto, é impossível que não influenciem em suas concepções morais sobre o que é correto ou incorreto, sobre o que é bom ou mau. Os legisladores e os funcionários públicos estão influenciados em sua visão de mundo pelas suas respectivas religiões e cosmovisões. Mas há dois aspectos que modificam completamente a definição dessa moral pública em uma sociedade secularizada e em um Estado laico: em primeiro lugar, em virtude do crescente papel da liberdade de consciência, ou seja, da faculdade de decidir o que é bom ou mau a partir de uma relação direta de cada indivíduo com seu Deus e já não necessariamente através da intervenção eclesiástica, a moral já não pode estar definida por uma hierarquia e sua interpretação da doutrina. A segunda razão é que os legisladores e funcionários públicos, mesmo que tenham suas crenças pessoais (religiosas ou de outro tipo), não devem nem podem impô-las à população. Legisladores e funcionários públicos devem responder essencialmente ao interesse público, que pode ser distinto de suas crenças pessoais. Assim, por exemplo, um legislador pode não estar de acordo com o uso do preservativo, mas está obrigado a criar leis que permitam e divulguem o uso do mesmo, para combater a epidemia da AIDS, a qual constitui um problema de saúde pública. Da mesma maneira, um legislador pode pessoalmente não estar de acordo com o aborto sob certas circunstâncias, mas a saúde pública o obriga a que o Estado atenda um problema existente, como o dos abortos realizados clandestinamente e em condições de insalubridade, o que provoca a morte de algumas mulheres que o fazem (BLANCARTE, 2008, p. 27).
\end{abstract}

Vejamos a seguir como o STF tem se comportado frente a questões dessa ordem.

\title{
5 PAPEL DO STF NA EDIFICAÇÃO DO ESTADO LAICO BRASILEIRO
}

Apesar da oficial laicização do Estado brasileiro desde os primeiros anos da República, a forte influência histórica e cultural da Igreja Católica Apostólica Romana, religião oficial do Brasil no período imperial, fez com que a onipresença dos preceitos religiosos permanecesse em grande medida legislativa ou jurisprudencialmente. Em razão da resistência do clero católico, a lei do divórcio demorou décadas para ser aprovada, ainda assim somente o foi na década de 70 do século passado e sob fortes protestos e pressões contrárias. Desnecessariamente foi incluído no preâmbulo da Constituição de 1988 uma alusão à "proteção de Deus" quando até mesmo constituições de Estados oficialmente confessionais dispensam essa referência, como nos casos da Argentina, Dinamarca e Suécia.

Aliás, foi sobre a natureza jurídica do preâmbulo da Carta de 1988 e a discussão, com base na simetria federativa, acerca da sua reprodução obrigatória nas constituições estaduais, que o STF proferiu uma das primeiras decisões mais contundentes sobre a laicidade do Estado brasileiro. Veja-se algumas passagens do julgado proferido na ADI 2076-5/AC (Rel. Min. Carlos Velloso, DJ 08/08/2003):

Essa invocação, todavia, posta no preâmbulo da Constituição Federal, reflete, simplesmente, um sentimento deísta e religioso, que não se encontra inscrito na Constituição, mesmo porque o Estado brasileiro é laico, consagrando a Constituição a liberdade de consciência e de crença $\left(\mathrm{CF}\right.$, art. $\left.5^{\circ}\right)$, certo que ninguém será privado de direitos por motivo de crença religiosa ou de convicção filosófica ou política (CF, art. $5^{\circ}$, VIII).

A Constituição é de todos, não distinguindo entre deístas, agnósticos ou ateístas. A referência ou a invocação à proteção de Deus não tem maior significação, tanto que Constituições de Estados cuja população pratica, em sua maioria, o teísmo, não contém essa referência. Menciono, por exemplo, as Constituições dos Estados 


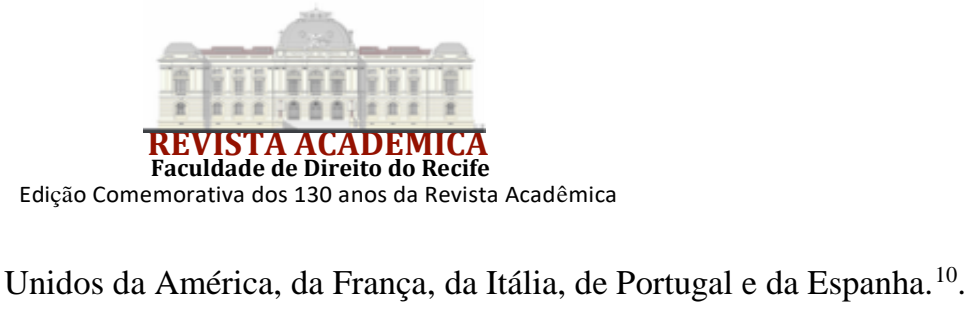

Se a decisão do STF sobre a natureza jurídica do preâmbulo possui maior significação simbólica que prática, o mesmo não se pode dizer do conteúdo decisório em outros julgados de inequívoco desdobramento concreto para milhões de pessoas. A seguir, são analisadas as que considerei mais destacadas diante de sua abrangência e visibilidade midiática, como adiantei na Introdução.

\subsection{STF, CIÊNCIA E CONCEPÇÕES RELIGIOSAS DE VIDA}

\subsubsection{Biodireito e a questão das células-tronco embrionárias}

O primeiro dos casos a ser analisado é o julgado referente à constitucionalidade das pesquisas com células-tronco embrionárias.

A ADI 3510 foi proposta pelo então Procurador Geral da República, Cláudio Fonteles, em face do art. $5^{\circ}$ da Lei 11105/2005 11 - a Lei da Biossegurança - que permite, para fins de pesquisa e terapia, a utilização de células-tronco embrionárias obtidas de embriões humanos produzidos por fertilização in vitro e não usados no respectivo procedimento, e estabelece condições para essa utilização. O PGR argumenta que o dispositivo ataca a inviolabilidade do direito fundamental à vida, considerando que esta inicia "na, e a partir da, fecundação", sendo o embrião, portanto, uma vida humana.

Diante da polêmica que inevitavelmente se seguiu, o Relator da referida Ação, Min. Ayres Britto, convocou, como lhe faculta o art. $7^{\circ}, \S 2^{\circ}$ da Lei 9868/1999, várias entidades representativas da comunidade científica e da sociedade civil para contribuírem com o debate na condição de amicus curiae. Foram elas: CONECTAS Direitos Humanos, CDH - Centro de Direitos Humanos, MOVITAE - Movimento em Prol da Vida, ANIS - Instituto de Bioética, Direitos Humanos e Gênero e CNBB - Conferência Nacional dos Bispos do Brasil. Todas elas tiveram oportunidade de se pronunciar na Corte e apresentarem seus pontos de vista sobre a temática envolvida.

No resumo feito pelo Min. Relator, é perceptível a existência de duas correntes científicas antagônicas sobre o tema, sendo uma delas defensora da fecundação como momento de início da vida, o que implicaria a prática abortiva em caso de efetivação das pesquisas e a outra afirmando a necessidade de intervenção humana para viabilização da vida do embrião congelado, não podendo ser equiparado a aborto a pesquisa em células dos referidos embriões.

A primeira posição coincide com a visão oficial da Igreja Católica acerca do início da vida. A Igreja se posicionou favoravelmente à procedência da ADI proposta pelo PGR, defendendo publicamente a declaração de inconstitucionalidade do referido dispositivo legal e a proibição das pesquisas com as referidas células (Oliveira Jr.: 2009). Algumas Igrejas evangélicas/protestantes adotaram posicionamento idêntico.

Entretanto, é evidente a ausência de consenso científico acerca da tormentosa questão desse

${ }^{10}$ No mesmo julgado, o Min. Sepúlveda Pertence chega a ser irônico: “Esta alocução 'sob a proteção de Deus', não é uma norma jurídica, até porque não se teria a pretensão de criar obrigação para a divindade invocada.”. A título comparativo, não é diferente a percepção da Suprema Corte do Canadá acerca do preâmbulo de sua Constituição, parecido com o da brasileira nesse particular. Cf. Vieytez, 2007, p. 181.

${ }^{11}$ Lei $11105 / 2005$, art. 5 ${ }^{\circ}$. É permitida, para fins de pesquisa e terapia, a utilização de células-tronco embrionárias obtidas de embriões humanos produzidos por fertilização in vitro e não utilizados no respectivo procedimento, atendidas as seguintes condições: I - sejam embriões inviáveis; ou II - sejam embriões congelados há 3 (três) anos ou mais, na data da publicação desta Lei, ou que, já congelados na data da publicação desta Lei, depois de completarem 3 (três) anos, contados a partir da data de congelamento. $\S 1^{\circ}$. Em qualquer caso, é necessário o consentimento dos genitores. $\S 2^{\circ}$. Instituições de pesquisa e serviços de saúde que realizem pesquisa ou terapia com células-tronco embrionárias humanas deverão submeter seus projetos à apreciação e aprovação dos respectivos comitês de ética em pesquisa. $\S 3^{\circ}$. É vedada a comercialização do material biológico a que se refere este artigo e sua prática implica o crime tipificado no art. 15 da Lei 9434, de 4 de fevereiro de 1997. 


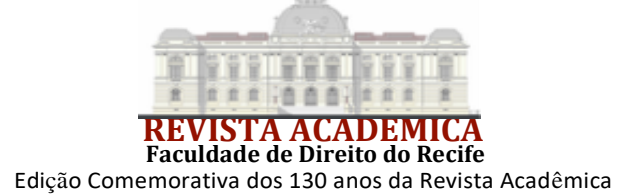

início e a posição favorável à constitucionalidade da lei aponta para diferenças essenciais entre aborto e as pesquisas em questão, de modo que estas últimas seriam possíveis sem que houvesse qualquer violação do direito à vida. Ademais, a potencialidade das pesquisas com células-tronco embrionárias para doenças graves, especialmente as neurovegetativas, é generalizadamente aceita até mesmo para os cientistas do grupo favorável à posição católica.

O STF, considerando as profundas divergências na comunidade científica, levou adiante uma ponderação dos interesses em jogo, optando por um posicionamento favorável à constitucionalidade do artigo em questão na sua integralidade, seguindo a maioria dos Ministros o voto do Min. Relator, Ayres Britto. Votaram integralmente com ele as Mins. Carmem Lúcia e Ellen Gracie e os Mins. Celso de Mello, Joaquim Barbosa e Marco Aurélio. Foram vencidos em diferentes questões os Mins. Cézar Peluso, Eros Grau, Gilmar Mendes, Ricardo Lewandowski e Menezes Direito, sendo que somente este último votou substancialmente de acordo com a posição da Igreja e dos cientistas do primeiro grupo, tamanhas as restrições feitas em seu voto às pesquisas em questão; os demais foram votos vencidos em questões pontuais, mas concordaram com a maioria das ponderações do voto do Min. Relator (ADI 3510, Rel. Min. Ayres Britto, DJe 28/05/2010).

Os Ministros procuraram se afastar dos argumentos mais associados a posições de influência religiosa, apontando para, diante das divergências, definir posição mais consentânea com aquilo que o Min. Ayres Britto denomina em muitos de seus votos e em obra doutrinária de "constitucionalismo fraternal" (cf. BRITTO, 2003, p. 216 et seq.). Afirmaram a legitimidade constitucional das pesquisas com células-tronco embrionárias principalmente pela sua potencial viabilização do direito fundamental à saúde como corolário da dignidade humana, bem como os direitos à autonomia da vontade, ao planejamento familiar e à maternidade, considerando suficientes as cautelas empreendidas pelo legislador no próprio texto legal.

No caso desta ADI, percebe-se que o STF não legislou obliquamente, mas corroborou essencialmente com o legislador, chancelando sua vontade expressa na Lei de Biossegurança. Contudo, pode-se afirmar algum grau de legalidade oblíqua aqui, considerando-se que as pesquisas com células-tronco só começaram efetivamente a serem realizadas quando o Tribunal confirmou a integral constitucionalidade do dispositivo em questão, no que me arrisco a afirmar que o STF, involuntariamente, funcionou na prática como uma terceira casa legislativa. ${ }^{12}$

Não há certeza, igualmente, quanto à existência do aspecto contramajoritário na questão. Não obstante mais de $70 \%$ dos brasileiros se afirmarem cristãos católicos, pesquisa realizada pelo Ibope pouco antes da decisão do STF apontava $75 \%$ dos brasileiros se pronunciando favoravelmente às pesquisas com células-tronco embrionárias, mesmo dentre os católicos, o que demonstra, no caso específico, uma divergência entre o posicionamento do clero católico e de seus fiéis (https://g1.globo.com/Noticias/Ciencia/0,MUL337154-5603,00DAS+PESSOAS+APOIAM+PESQUISA+COM+CELULASTRONCO+DIZ+IBOPE.html.

Acesso em: 10 nov. 2021).

\subsubsection{Anencefalia e aborto consentido}

O segundo caso a ser analisado neste ensaio sobre a legalidade oblíqua promovida pelo STF em relação ao Estado laico é a decisão proferida pelo Tribunal em relação à possibilidade de

\footnotetext{
${ }^{12}$ Defendendo certo ativismo do STF nesta e em outras questões, Gilmar Mendes toma emprestada reflexão de Robert Alexy no sentido de que "o parlamento representa o cidadão politicamente, o tribunal constitucional argumentativamente", para, a seguir, arrematar sobre a ADI 3510/DF: "Naquela ação direta, dentre os muitos aspectos que poderiam ser destacados, chama a atenção o fato de a Suprema Corte ter demonstrado postura ativa na condução de tema de tamanha relevância para a sociedade. Sobre isso, consignei que a alternativa da atitude passiva de self restraint - ou, em certos casos, de greater restraint, utilizando a expressão de García de Enterría - teria sido mais prejudicial ou menos benéfica para a nossa democracia” (MENDES, 2011, p. 67, grifos do autor).
} 


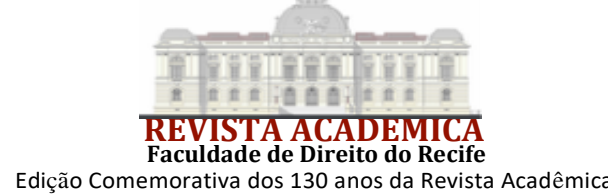

interrupção da gestação em razão de gravidez de feto anencéfalo.

A ADPF 54 foi ajuizada pela CNTS - Confederação Nacional dos Trabalhadores na Saúde, com a finalidade de declarar a inconstitucionalidade de interpretação que considerasse a interrupção da gravidez de feto anencéfalo como conduta típica presente nos arts. 124, 126 e 128, I e II, do Código Penal.

A Relatoria do feito coube dessa vez ao Min. Marco Aurélio. Mais uma vez o recurso aos amici curiae foi feito pelo STF, sendo convocadas a opinar e expor seus pontos de vista as seguintes entidades representativas da sociedade civil: CNBB - Conferência Nacional dos Bispos do Brasil, Igreja Universal do Reino de Deus, Associação Nacional Pró-Vida e Pró-Família, ONG Católicas pelo Direito de Decidir, AME - Associação Médico-Espírita do Brasil, CFM - Conselho Federal de Medicina, Federação Brasileira das Associações de Ginecologia e Obstetrícia, Sociedade Brasileira de Medicina Fetal, Sociedade Brasileira de Genética Médica, SBPC Sociedade Brasileira para o Progresso da Ciência, ANIS - Instituto de Bioética, Direitos Humanos e Gênero, ADEF - Associação de Desenvolvimento da Família, ONG Escola de Gente Comunicação em Inclusão, Rede Nacional Feminista de Saúde, Direitos Sexuais e Direitos Reprodutivos, Conselho Federal dos Direitos da Mulher, CONECTAS Direitos Humanos, Conselho Nacional dos Direitos da Mulher e Associação Brasileira de Psiquiatria. Também foram convocadas as seguintes pessoas físicas: Dep. Fed. José Aristodemo Pinotti (Assessor da OMS para Assuntos da Mulher), Dep. Fed. Luiz Bassuma (Presidente da Frente Parlamentar em Defesa da Vida - Contra o Aborto), Profa. Lenise Aparecida Martins Garcia (Professora Titular da UnB e Presidente do Movimento Nacional da Cidadania em Defesa da Vida - Brasil sem Aborto), Min. José Gomes Temporão (Médico e Ministro de Estado da Saúde), Dra. Cinthia Macedo Specian (Pediatra), Dr. Denivaldo da Silva Brandão (Ginecologista e Obstetra, Presidente da Comissão de ética e Cidadania da Academia Fluminense de Medicina) e Dra. Elizabeth Kipman Cerqueira (Ginecologista e Obstetra, Professora Adjunta da Faculdade de Ciências Médicas da Santa Casa de São Paulo).

É perceptível que nesse feito temos novamente discussões científicas e éticas, talvez ainda mais complexas que a das células-tronco, pois nos casos em questão a gravidez se consuma e o feto existe em uma gestação concreta. Ademais, há a relevância dos perigos dos erros de diagnóstico.

Não há novidades na posição da Igreja Católica. Coerente com o que defendeu na ADI 3510, a Igreja considera o feto um ser humano vivo e não aceita o aborto em hipótese alguma, nem mesmo nos casos legalmente previstos no $\mathrm{CP}$, posição que se repete nos casos de anencefalia. $\mathrm{O}$ dissenso aqui foi grande entre as entidades e pessoas também foi significativo, o que refletiu em alguma medida na decisão de mérito que, do ponto de vista argumentativo, não foi tão convergente como a da questão das células-tronco embrionárias.

No seu voto, o Min. Marco Aurélio destacou haver conflito em tais casos entre os interesses legítimos da mulher em se ver respeitada em sua dignidade e os de parte da sociedade que desejasse proteger todos os que a integrariam, independentemente da condição física ou viabilidade de sobrevivência. Ainda segundo o voto, a má formação congênita letal característica da anencefalia não permitiria sobrevida em termos de desenvolvimento de massa encefálica. $O$ feto anencéfalo não desfrutaria de nenhuma função superior do sistema nervoso central, responsável pela consciência, cognição, vida relacional, comunicação, afetividade e emotividade. Destacou a Resolução 1752/2004 do CFM que, com base no critério médico de diagnóstico do falecimento pela morte cerebral, os anencéfalos seriam natimortos cerebrais. Rechaçou que tal prática configuraria aborto eugênico, diferenciando substancialmente os anencéfalos dos fetos com deficiências que não inviabilizariam a vida extrauterina. Por tais motivos, asseverou que a interrupção da gestação do anencéfalo não configuraria crime contra a vida, mas conduta atípica. Advertiu o Min. Relator que nas décadas de 30 e 40 do século passado, a medicina não possuía recursos técnicos necessários para identificar previamente a anomalia fetal, por isso, a literalidade 


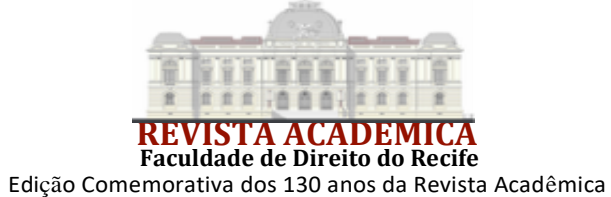

do Código Penal estava em harmonia com o nível de diagnósticos médicos existentes à época, o que explicaria a ausência de dispositivo que previsse expressamente a atipicidade da interrupção da gravidez de feto anencefálico. Nesse aspecto, relembrou que se trata do mesmo legislador que, para proteger a honra e a saúde mental ou psíquica da mulher, considerara impunível o aborto provocado em gestação oriunda de estupro em hipótese de feto plenamente viável. Assim, o Min. Marco Aurélio entendeu ser lógico que, apesar da falta de previsão expressa no Código Penal de 1940, o feto sem potencialidade de vida não pode ser tutelado pelo tipo incriminador em questão. Ainda considerou desproporcional a exigência do sacrifício desarrazoado por parte da mulher de levar contra sua vontade uma gestação até o seu fim, não obstante a inviabilidade da vida extrauterina daquele ser.

Diante das investidas, inclusive midiáticas, dos setores religiosos, o Min. Relator salientou a laicidade como princípio fundamental do Estado democrático brasileiro, princípio este que atuaria de modo dúplice: a um só tempo, salvaguardaria as diversas confissões religiosas do risco de intervenção abusiva do Estado em suas questões internas e protegeria o Estado de influências indevidas provenientes de dogmas de cariz religioso, de modo a afastar a prejudicial confusão entre o poder secular e democrático e qualquer doutrina de fé, mesmo que majoritária. Ressaltou que as garantias do Estado secular e da liberdade de culto não permitem que as religiões guiem a partir de seus dogmas de fé o tratamento estatal dispensado a outros direitos fundamentais, tais como os direitos à autodeterminação, à saúde física e mental, à privacidade, à liberdade de expressão, à liberdade de orientação sexual e à liberdade no campo da reprodução. Portanto, a questão debatida não poderia ser examinada sob os influxos de orientações morais religiosas, apesar de a oitiva de entidades ligadas a profissão de fé não ter sido em vão. Isso porque, em uma democracia, não seria legítimo excluir qualquer ator do âmbito de definição do sentido da Constituição. Entendeu, todavia, que para se tornarem aceitáveis no debate jurídico, os argumentos provenientes dos grupos religiosos deveriam ser devidamente "traduzidos" em termos de razões públicas, ou seja, expostos de forma que a adesão a eles independa da crença pessoal. Ainda destacou que a crença religiosa não pode conduzir à incriminação de suposta conduta de mulheres que optem por não levar a gravidez a termo, visto que ações avaliadas socialmente como meramente imorais não mereceriam glosa do direito penal.

A fundamentação do Min. Relator, não obstante cientificamente densa, é também fortemente laicista. Com base nesses argumentos, com pequenos adendos, decidiu o STF por maioria pela procedência da ADPF 54. Votaram com o Min. Marco Aurélio, as Mins. Carmem Lúcia e Rosa Weber e os Mins. Ayres Britto, Celso de Mello, Gilmar Mendes (muito embora tenha entendimento que não é caso de atipicidade penal, mas de excludente de ilicitude, o que não muda substancialmente o resultado do julgamento) e Luiz Fux.

Foram votos contrários os dos Mins. Cézar Peluso e Ricardo Lewandowski. O primeiro entendeu que eram completamente diferentes as situações da ADI 3510 e da ADPF 54, considerando que as excludentes legais não comportam o caso do anencéfalo e não poderia o STF ampliá-las. Levou o argumento ao extremo, equiparando a defesa do aborto do anencéfalo a casos de racismo, sexismo e especismo, bem como eugenia ou até, no limite, a admissão de sacrifícios humanos em cultos satânicos. O segundo, com argumentos mais ponderados, salientou o papel de legislador negativo do STF, de certo modo condenando uma postura excessivamente ativista por parte do Tribunal que, em sua visão, estaria se colocando no papel do Congresso Nacional que poderia já ter aprovado tal hipótese de atipicidade penal ou de excludente de ilicitude e ainda não o fez.

Os Mins. Dias Toffoli e Joaquim Barbosa não participaram do julgamento, o primeiro por se arguir suspeito diante da anterior participação no mesmo processo como Advogado Geral da União e o segundo por razões de saúde (ADPF 54, Rel. Min. Marco Aurélio, DJe 30/04/2013).

Neste caso a promoção de uma legalidade oblíqua do STF foi bastante intensa. Considerando que as excludentes de punibilidade não compreendem o caso do anencéfalo, pode- 


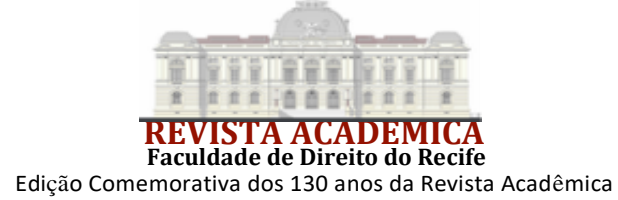

se afirmar que a atualização legislativa feita pelo Tribunal foi uma espécie de legislação oblíqua em nome do rule of law, muito embora nenhum dos Ministros tenha afirmado isso de modo expresso.

Entretanto, talvez não seja um caso de contramajoritariedade, se considerarmos que o apoio ao direito da mulher a interromper a gravidez de um anencéfalo é consideravelmente alto na população em geral e mesmo entre os católicos, de acordo com pesquisa do Ibope realizada em 2004. Dos entrevistados pelo Instituto, 70,5\% da população geral e 72,2\% dos declarados católicos disseram concordar que a mulher grávida de um feto anencéfalo pode escolher se interrompe ou não a gestação; para 77\% é obrigação do Estado atender as mulheres; para 71\%, obrigar uma mulher a manter até o final a gestação de um feto com essa anomalia, contra sua vontade, é uma forma de tortura. Entre os católicos, o número sobe para 72,5\%. Já para 77,6\%, os hospitais públicos têm o dever de atender a mulher que optar pela interrupção da gravidez nesses casos, índice que aumenta para $78,7 \%$ entre católicos (http://www.redebrasilatual.com.br/temas/cidadania/2012/04/stf-decide-sobre-aborto-deanencefalo-nesta-quarta-11. Acesso em: 10 nov. 2021).

\subsection{STF, A PROTEÇÃO AOS DIREITOS LGBTQIA+ E A OPOSIÇÃO RELIGIOSA}

\subsubsection{União estável e homoafetividade}

O primeiro caso de legalidade oblíqua promovida pelo STF para proteção de direitos LGBTQIA+ diz respeito ao reconhecimento feito por esse Tribunal das uniões estáveis homoafetivas, equiparando-as às uniões estáveis de casais heteroafetivos, expressamente previstas no art. 226, § $3^{\circ}$, da Constituição de 1988.

Aqui se trata do julgamento da ADI 4277/DF que, para efeito de julgamento, resultou da convergência de objetos de ações abstratas de controle de constitucionalidade. A finalidade da referida ação foi dar interpretação conforme a constituição ao art. 1723 do Código Civil, que regulamenta o aludido dispositivo constitucional referente à união estável, ampliando a interpretação do dispositivo para além da literalidade (união entre "homem e mulher") e com isso alcançar as uniões de pessoas do mesmo sexo.

A incumbência de relatar o feito ficou com o Min. Ayres Britto. Da mesma forma como na ADI 3510, o Min. Relator convidou para o papel de amicus curiae diversas entidades da sociedade civil, algumas delas, aliás, que haviam desempenhado tal papel naquela outra Ação. Foram elas: CONECTAS Direitos Humanos, ABGLT - Associação Brasileira de Gays, Lésbicas e Transgêneros, Grupo Arco-Íris de Conscientização Homossexual, GEDI/UFMG - Grupo de Estudos de Direito Internacional da Universidade Federal de Minas Gerais, Centro de Referência GLBTTT de Minas Gerais, ANIS - Instituto de Bioética, Direitos Humanos e Gênero, Associação de Incentivo à Educação e Saúde de São Paulo, IBDFAM - Instituto Brasileiro de Direito de Família, Associação Eduardo Banks e CNBB - Conferência Nacional dos Bispos do Brasil.

Diferentemente do primeiro caso, aqui não tivemos discussão científica, já que a questão envolvida é eminentemente jurídico-sociológica. De um lado os que defendem a referida equiparação entre uniões estáveis de pessoas do mesmo sexo e de sexos diferentes como corolário do princípio da igualdade, da autonomia da vontade, bem como da não discriminação por motivo de orientação sexual. De outro os que condenam tais uniões com uma fundamentação essencialmente religiosa a partir de passagens bíblicas como as que se seguem:

Com homem não te deitarás, como se fosse mulher; é abominação. (LEVÍTICO, 19:22)

Se também um homem dormir com outro homem, como se fosse com mulher, ambos fizeram abominação. Certamente serão mortos, e o seu sangue será sobre eles. (LEVÍTICO, 20:13)

Semelhantemente, também os homens, deixando o uso natural da mulher, 


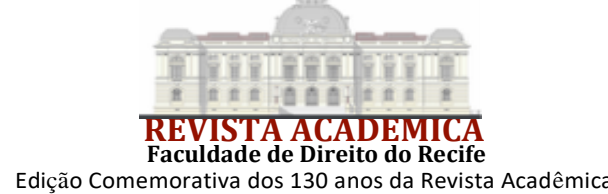

inflamaram-se em sua sensualidade uns para com os outros, homem com homem, cometendo torpeza, e recebendo em si mesmos a penalidade devida ao seu erro. (ROMANOS, 1:27) ${ }^{13}$.

É evidente que aqui se trata de um confronto direto entre uma percepção laica do Estado de direito e outra confessional. Por mais que segmentos religiosos possam afirmar que Deus condenaria a homossexualidade ou que é um pecado, o máximo que padres e pastores podem fazer em um Estado laico é recomendar aos seus fiéis que não pratiquem tais atos, mas não querer condicionar a vida de pessoas - que não professam a mesma fé ou que não concordam com essas passagens bíblicas ou que as interpretam diferentemente - a seguirem um modelo de vida afetiva e sexual baseada em princípios específicos de uma dada religião, ainda que majoritária, e não na autonomia da vontade e na própria liberdade de consciência e de crença preconizadas pelo Estado laico e constitucionalmente reconhecidas.

Talvez por essa desproporção argumentativa, a decisão do STF reconhecendo as uniões homoafetivas como juridicamente equiparadas às heteroafetivas não teve nenhum voto contrário, sendo um caso de votação unânime pelos Ministros daquele Tribunal. Dez deles votaram a favor da referida equiparação e apenas o Min. Dias Toffoli se declarou impedido por ter atuado anteriormente na mesma Ação como Advogado Geral da União. Participaram do julgamento os Mins. Ayres Britto (Relator), Carmem Lúcia, Celso de Mello, Cézar Peluso, Ellen Gracie, Gilmar Mendes, Joaquim Barbosa, Luiz Fux, Marco Aurélio e Ricardo Lewandowski.

Esteve presente a tese do constitucionalismo fraternal, que levou os julgadores a considerar, dentre outras coisas, que a proibição da discriminação em razão do sexo alcançaria tanto a dicotomia homem/mulher (gênero), como a orientação sexual de cada um deles. Nas liberdades constitucionais está a de dispor sobre a própria sexualidade e a equiparação em questão fortalece, na visão do STF, direitos fundamentais como a autonomia da vontade, a intimidade e a vida privada. Ainda aponta para o aspecto sócio-cultural e não estanque do conceito de família, reconhecendo, afinal, a união homoafetiva como entidade familiar (ADI 4277, Rel. Min. Ayres Britto, DJe 14/10/2011). Em adendo, recorde-se que, não obstante não haver previsão expressa da possibilidade de uniões estáveis homoafetivas, em nenhum dispositivo há proibição delas, o que permite o entendimento de que sua extensão a outros casos para ampliação de direitos é perfeitamente plausível e razoável, bem como juridicamente justificável.

Interessante notar que, diferentemente do primeiro caso, aqui tivemos todos os componentes de uma legalidade oblíqua contramajoritária construída pelo STF. Por mais justa que tenha sido a decisão, o fato é que o Tribunal, através da interpretação conforme a Constituição, criou nova hipótese legislativa não contida expressamente no texto constitucional ou no Código Civil. E, apesar da unanimidade tribunalícia, trata-se de decisão francamente contramajoritária, já que há pesquisas realizadas à época como a do Ibope feita entre 14 e 18 de julho de 2011 que apontam para um percentual de $55 \%$ dos brasileiros se declarando contrários a tais uniões, chegando esse índice a $77 \%$ quando pesquisados apenas os cristãos evangélicos/protestantes (Disponível em: https://noticias.uol.com.br/cotidiano/ultimas-noticias/2011/07/28/evangelicossao-os-mais-resistentes-a-uniao-homoafetiva-aponta-ibope.htm. Acesso em: 10 nov. 2021).

\subsubsection{Transexualidade e direito à identidade de gênero}

O segundo caso de legalidade oblíqua promovida pelo STF para proteção de direitos LGBTQIA+ diz respeito ao direito das pessoas transgênero de terem alterados seu prenome e sexo

${ }^{13}$ Saliente-se que há controvérsias em torno das traduções dessas e de outras passagens da Bíblia, havendo inclusive vários hermeneutas ligados às chamadas igrejas inclusivas que apresentam estudos e pesquisas que questionam algumas delas em relação a isso, mas em um trabalho eminentemente jurídico como este, não nos cabe entrar em debates de natureza linguístico-teológica. 


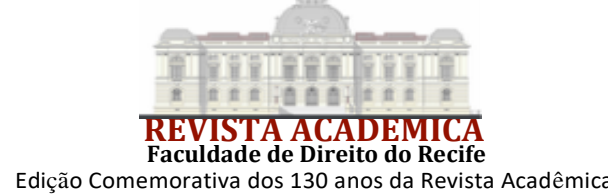

no registro civil sem a necessidade de cirurgia de transgenitalização.

Uma das questões mais tormentosas historicamente para a vida social de pessoas transgênero é a de um direito de personalidade básico, o direito ao próprio nome. Por não se identificarem com seu gênero atribuído no nascimento a partir da genitália, tais pessoas passam a se apresentar socialmente como do gênero com o qual se identificam, havendo, portanto, uma incongruência não somente em relação ao aspecto físico-social, mas também documental. Como nos documentos de identificação de homens trans permanece inicialmente o prenome feminino e o mesmo acontecendo com as mulheres trans em relação ao prenome masculino, tal circunstância acarreta constrangimentos sociais cotidianos, pois a pessoa com aparência masculina é identificada com nome feminino e a pessoa com aparência feminina identificada com o nome masculino.

As pessoas transgênero normalmente já se apresentam com seus nomes sociais do gênero com o qual se identificam. Porém, há uma série de dificuldades e empecilhos burocráticos para que em sua documentação oficial pudesse estar o prenome correspondente à sua identidade de gênero, sendo a mais comum delas a exigência de que elas tivessem feito a cirurgia de transgenitalização para que pudessem ter deferida a mudança de nome, e ainda assim após uma batalha judicial nem sempre exitosa.

Em razão dessa situação, o Procurador Geral da República ingressou com ADI em julho de 2009 pleiteando fosse dada ao art. 58 da Lei 6015/1973 (Lei de Registros Públicos) interpretação conforme à Constituição para que as pessoas transgênero pudessem ter direito à alteração do prenome e sexo no Registro Civil, independentemente da realização de cirurgia de transgenitalização.

A Relatoria coube ao Min. Marco Aurélio. Foram aceitas na condição de amicus curiae as seguintes entidades: IBDFAM - Instituto Brasileiro de Direito de Família, GADVS - Grupo de Advogados pela Diversidade Sexual, ABGLT - Associação Brasileira de Gays, Lésbicas e Transgêneros, Grupo Dignidade - Pela Cidadania de Gays, Lésbicas e Transgêneros, LIDIS Laboratório Integrado em Diversidade Sexual e de Gênero, Políticas e Direitos, CLAM - Centro Latino-Americano em Sexualidade e Direitos Humanos e Conselho Federal de Psicologia. Também foi admitido como amicus curiae o Defensor-Público Geral Federal.

É curioso notar que, diferentemente do caso da ADI 4277, este aqui não comportou debates de natureza religiosa, bem como não integraram o processo na qualidade de amicus curiae entidades representativas de qualquer religião, cingindo-se as discussões aos aspectos de direito registral e de direitos fundamentais das pessoas trans.

A título de contraditório, o único no processo que se insurgiu de modo totalmente contrário ao pleito foi o Presidente do Senado Federal, representando esta Casa. Alegou que o poder público promove de modo eficiente os direitos das pessoas trans e que assegura na rede pública a cirurgia de transgenitalização ${ }^{14}$, considerando inviável a alteração no registro sem a intervenção cirúrgica por que seria imprescindível que o registro correspondesse à realidade física. Ademais, afirma que o judiciário não poderia avançar nessa seara, pois estaria fazendo o papel de legislador positivo.

$\mathrm{Na}$ decisão, nenhum dos Ministros levou tais alegações em consideração. Embora o julgamento não tenha sido unânime, a divergência entre os Ministros se deu basicamente em uma questão secundária, em relação à necessidade de submeter à alteração de prenome e sexo à jurisdição voluntária, portanto, a uma atuação do Estado-juiz ou, ao contrário, fazê-la diretamente no cartório de registro civil, tendo sido vencedora essa última tese a partir da divergência aberta no julgamento pelo Min. Edson Fachin. Seguiram o voto divergente os Mins. Celso de Mello, Luiz Fux e Roberto Barroso e as Mins. Carmem Lúcia e Rosa Weber. Foram vencidos nesse particular o Min. Relator Marco Aurélio e os Mins. Alexandre de Moraes, Gilmar Mendes e Ricardo Lewandowski. Não votou o Min. Dias Toffoli por impedimento (ADI 4275, Rel. p/ Acórdão Min.

14 O que precisa ser devidamente contextualizado, pois embora alguns hospitais públicos de fato realizem a referida cirurgia, a espera por ela pode chegar a 18 anos... - cf. https://www.otempo.com.br/brasil/cirurgias-dereadequacao-sexual-desabam-e-espera-da-populacao-trans-se-prolonga-1.2438783. Acesso em: 10 nov. 2021. 
Edson Fachin, DJe 07/03/2019).

Contudo, é interessante notar que em relação à exigência da cirurgia de transgenitalização para assegurar o direito à mudança de prenome e sexo no registro civil, a Corte entendeu por unanimidade ser esta desnecessária. Nem mesmo tratamentos hormonais e congêneres são considerados exigíveis, pois a identidade de gênero foi considerada direito fundamental ao livre desenvolvimento da personalidade, cabendo ao Estado apenas o papel de reconhecê-la, nunca de constitui-la, sendo a autodeclaração de vontade oficialmente firmada elemento suficiente para que tais atos sejam realizados no âmbito dos registros públicos.

Embora também a transexualidade, como muitos dos direitos LGBTQIA+, seja um tema tabu para muitas religiões, talvez pela ausência de entes religiosos, os argumentos dessa natureza não foram referidos ao longo do julgamento.

Em outro aspecto, é de se observar que ao menos em termos de colmatação de lacunas legislativas, a legalidade oblíqua e provavelmente contramajoritária aqui também esteve presente, não obstante não haver na literalidade da norma dos registros públicos de 1973 qualquer empecilho a uma ampliação de hipóteses a partir da interpretação conforme à Constituição feita no julgado objeto de análise.

\subsubsection{Criminalização da LGBTfobia}

O terceiro caso envolvendo a defesa do Estado laico em relação aos direitos LGBTQIA+ é mais delicado, envolvendo uma controvérsia significativamente maior do que os anteriores.

De um lado, temos o histórico de enorme violência cometida contra esse segmento vulnerável da população em razão de sua orientação sexual e identidade de gênero. E há mesmo um mandamento constitucional para que condutas do tipo sejam punidas, como se pode perceber do art. 5\%, XLI ("a lei punirá qualquer discriminação atentatória dos direitos e liberdades fundamentais"). Ademais, há uma flagrante ausência de isonomia em existir desde 1989 uma lei que pune criminalmente discriminações e preconceitos raciais, étnicos, religiosos e de procedência nacional e a ausência de punição nos mesmos termos da discriminação e preconceito de natureza LGBTfóbica. Portanto, configura tal ausência uma flagrante e inconstitucional omissão por parte do Legislativo nacional brasileiro.

De outro, há a questão de que a punição de natureza criminal exige o respeito ao princípio da legalidade em sentido estrito, lei em sentido formal como ato do poder legislativo, no caso brasileiro, aliás, somente o Congresso Nacional. Por claro que seja o dispositivo constitucional em determinar a punição de todos esses atos discriminatórios LGBTfóbicos, não menos claro é o inciso XXXIX do mesmo art. $5^{\circ}$ ("não há crime sem lei anterior que o defina, nem pena sem prévia cominação legal"). E é fato igualmente relevante que é da tradição do constitucionalismo democrático a presunção a favor da liberdade e pela não criminalização sem base legal.

A controvérsia chegou ao STF através de ADO (Ação Direta de Inconstitucionalidade por Omissão) proposta pelo Partido Popular Socialista (PPS) em fins de 2013, tendo sido distribuída para Relatoria do Min. Celso de Mello. Participaram na condição de amicus curiae as seguintes entidades: GGB - Grupo Gay da Bahia, ABGLT - Associação de Lésbicas, Gays, Bissexuais, Travestis e Transexuais, GADVS - Grupo de Advogados pela Diversidade Sexual, ANAJURE Associação Nacional de Juristas Evangélicos, Frente Parlamentar "Mista" da Família e Apoio à Vida, Grupo Dignidade - Pela Cidadania de Gays, Lésbicas e Transgêneros, COBIM - Convenção Brasileira das Igrejas Evangélicas Irmãos Menonitas, PSTU - Partido Socialista dos Trabalhadores Unificado, Conselho Federal de Psicologia, ANTRA - Associação Nacional de Travestis e Transexuais e Defensoria Pública do Distrito Federal.

É de se notar que, diversamente do que ocorreu no caso anterior, já na participação de entes da sociedade civil na condição de amicus curiae, há uma quantidade razoável de representantes de segmentos religiosos, especialmente preocupados com eventual criminalização de suas pregações 


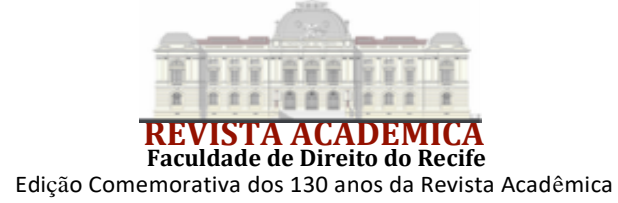

doutrinárias contrárias ao comportamento homoafetivo e ao que denominam "ideologia de gênero", referência pejorativa a teorias que defendem que o gênero é uma construção social, não um dado biológico.

Em linhas gerais, a ADO proposta pugna pela colmatação da lacuna legislativa decorrente do art. $5^{\circ}$, XLI, da Constituição da República, criminalizando a LGBTfobia a partir dos mesmos critérios punitivos para outros tipos de discriminação como os previstos na Lei 7716/1989, referentes, como já antecipado, a raça, cor, etnia, religião ou procedência nacional. Os argumentos presentes na Inicial e endossados por vários dos amici curiae ligados à defesa dos direitos LGBTQIA+, como GGB, ABGLT, GADVS, Grupo Dignidade - Pela Cidadania de Gays, Lésbicas e Transgêneros e ANTRA versam sobre a omissão inconstitucional do Congresso Nacional em criminalizar a homofobia e a transfobia, a premente necessidade de que tal penalização específica ocorra em face dos alarmantes dados sobre a recorrente violência sofrida por essa população vulnerável e a tese de que configuraria essa discriminação uma espécie de racismo em sua dimensão social, merecendo equiparação em termos de punibilidade, tal como a Lei equiparou a discriminação nos casos de etnia, religião e procedência nacional. Também entes não associados diretamente com a defesa desses direitos, como o Conselho Federal de Psicologia e o PSTU, corroboraram publicamente tais argumentos na condição de amigos da Corte.

Por outro lado, as entidades direta ou indiretamente associadas à religião que atuaram no feito na condição de amici curiae pugnaram pela improcedência da Inicial. Curiosamente, a Frente Parlamentar "Mista" da Família e Apoio à Vida, a COBIM e a ANAJURE não direcionaram seus argumentos para o mérito da questão. Suas alegações foram fundamentalmente de forma jurídica, defendendo que o sistema constitucional de freios e contrapesos não permitiria que o STF fizesse as vezes de legislador positivo, pois tratar-se-ia de uma usurpação inconstitucional de funções. Também destacam a inexistência de um mandamento constitucional específico de criminalização em relação à LGBTfobia, diferentemente do que ocorre com o racismo. O Advogado-Geral da União, como defensor legis, vai nessa linha argumentativa, assim como as informações prestadas pela Câmara dos Deputados e pelo Senado Federal, tendo a primeira até destacado a existência de vários projetos de lei em tramitação, tendo sido um deles aprovado por aquela Casa e já em debate no Senado.

Por maioria, o STF decidiu pela procedência da ADO 26, estabelecendo com eficácia erga omnes e efeito vinculante que: 1) há um estado de mora inconstitucional do Congresso Nacional na implementação da prestação legislativa destinada a cumprir os mandamentos de criminalização a que se referem os incisos XLI e XLII do art. $5^{\circ}$ da CF, para efeito de proteção penal às pessoas LGBTQIA+; 2) declarou, em consequência, a existência de omissão normativa inconstitucional do Poder Legislativo da União; 3) determinou a ciência do Congresso Nacional, para os fins e efeitos a que se refere o art. $103, \S 2^{\circ}$, da Constituição da República c/ o art. 12-H, caput, da Lei $\mathrm{n}^{\circ}$ 9.868/1999; 4) deu interpretação conforme à Constituição, em face dos mandamentos constitucionais de incriminação já referidos, para enquadrar a homofobia e a transfobia, qualquer que seja a forma de sua manifestação, nos diversos tipos penais definidos na Lei 7716/1989, até que sobrevenha legislação a respeito aprovada pelo Congresso Nacional, seja por considerar-se, nos termos deste voto, que as práticas homotransfóbicas qualificam-se como espécies do gênero racismo, na dimensão de racismo social consagrada pelo STF no famoso Caso Ellwanger ${ }^{15}$, na medida em que tais condutas importam em atos de segregação que inferiorizam membros integrantes da comunidade LGBTQIA+, em razão de sua orientação sexual ou de sua identidade de gênero, seja também porque tais comportamentos de LGBTfobia ajustam-se ao conceito de atos de discriminação e de ofensa a direitos e liberdades fundamentais daqueles que compõem o grupo vulnerável em questão; e 5) declarou que os efeitos da interpretação conforme somente serão obrigatórios a partir da data em que fosse concluído o julgamento.

${ }^{15}$ HC 82424/RS, Rel. p/ Ac. Min. Maurício Corrêa, DJe 19/03/2004.

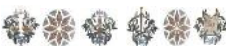

GALINDO, Bruno. O ESTADO LAICO SEGUNDO O SUPREMO TRIBUNAL FEDERAL: ASPECTOS DA LEGALIDADE OBLÍQUA E CONTRAMAJORITÁRIA NO BRASIL. Revista Acadêmica da Faculdade de Direito do Recife - ISSN: 24482307, Edição Comemorativa dos 130 anos da Revista Acadêmica, p. 56-79. Nov. 2021. ISSN 2448-2307. <Disponível em: https://periodicos.ufpe.br/revistas/ACADEMICA/article/view252585> 


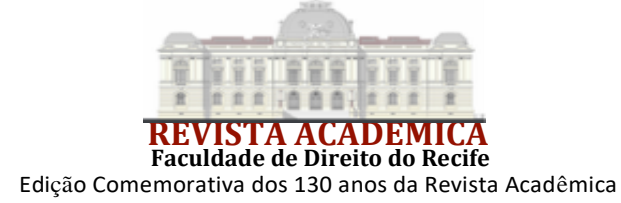

Para além disso, foram fixadas teses adicionais, como a que a repressão penal à prática da homotransfobia não alcança nem restringe ou limita o exercício da liberdade religiosa, qualquer que seja a denominação confessional professada, a cujos fiéis e líderes (padres, pastores, rabinos, clérigos islâmicos e celebrantes das religiões afrobrasileiras, entre outros) ficou assegurado o direito de pregar e de divulgar, livremente, pela palavra, pela imagem ou por qualquer outro meio, o seu pensamento e de externar suas convicções de acordo com o que se contiver em seus livros e códigos sagrados, bem assim o de ensinar segundo sua orientação doutrinária e/ou teológica, podendo fazer proselitismo e praticar os atos de culto e respectiva liturgia, independentemente do espaço, público ou privado, de sua atuação individual ou coletiva, desde que tais manifestações não configurem discurso de ódio, assim entendidas aquelas exteriorizações que incitem a discriminação, a hostilidade ou a violência contra pessoas em razão de sua orientação sexual ou de sua identidade de gênero (ADO 26, Rel. Min. Celso de Mello, DJe 06/10/2020).

Formaram a maioria pela procedência da ADO, além do Min. Celso de Mello como Relator, os Mins. Alexandre de Moraes, Edson Fachin, Gilmar Mendes, Luiz Fux e Roberto Barroso e as Mins. Carmem Lúcia e Rosa Weber. Votaram pela sua procedência parcial os Mins. Ricardo Lewandowski e Dias Toffoli, reconhecendo a mora inconstitucional do Congresso Nacional, mas entendendo pela impossibilidade do STF suprir a lacuna de modo direto no âmbito do direito penal ante o princípio da reserva legal. Apenas o Min. Marco Aurélio votou pela sua improcedência, entendendo pela ausência de uma obrigação específica do Legislativo nacional a respeito, bem como também aludindo ao princípio da reserva legal, que limitaria nesse particular a atuação da jurisdição constitucional.

Um dos dados relevantes é que em nenhum momento se negou a necessidade de punição de atos atentatórios a direitos e liberdades da população LGBTQIA+. Mesmo as entidades de caráter religioso não se posicionaram nesse sentido, menos ainda os votos vencidos, tendo eles uma preocupação - legítima, aliás, e que compartilho nesse particular ${ }^{16}$ - em torno da possibilidade de efetiva criação de tipos penais pela via judicial, o que de fato seria bastante temerário em um Estado constitucional e democrático de direito. Aqui o argumento confessional deu lugar a um debate jurídico sobre os limites e as possibilidades do nosso checks and balances system e uma preocupação com a ponderação de direitos, que, por sua vez, foi acolhida pela tese fixada no Acórdão de que, desde que não configure discurso do ódio e defesa de hostilidades contra a população LGBTQIA+, não seria considerada LGBTfobia para efeitos criminais a pregação doutrinária religiosa de acordo com seus próprios livros sagrados.

Em todos os casos aqui analisados, me parece ser este o que o STF mais avança em termos de construção de uma legalidade oblíqua e contramajoritária. Pessoalmente, ainda que concorde com a criminalização da LGBTfobia, tenho reservas quanto a essa extensão conceitual do racismo adotada pela decisão para que a Lei 7716/1989 alcance os atos discriminatórios LGBTfóbicos. A legalidade oblíqua e contramajoritária aqui, diferentemente dos demais casos, avança em um terreno perigoso de relativização do princípio da legalidade penal que aponta para a legalidade estrita, para a reserva legal, como aludido pelo Min. Ricardo Lewandowski. Por outro lado, não parece razoável a espera indefinida quanto ao cumprimento do mandamento de criminalização, sob pena de perpetuar a situação de omissão inconstitucional, haja visto que a discussão no âmbito do Congresso Nacional já chega a mais de duas décadas sem uma definição legal de punições para tal.

Em outro escrito, fiz uma proposta para tais situações que entendo compatibilizar a legalidade oblíqua e contramajoritária do STF a respeito com a necessidade de reverência ao trabalho legislativo e ao sistema de freios e contrapesos, limitando a atuação da jurisdição constitucional em avançar no plano da legislação positiva, apostando em um frutífero diálogo institucional entre Parlamento e Corte suprema. Minha sugestão para casos como este seria o STF:

${ }^{16}$ Cf. Galindo: 2019. 


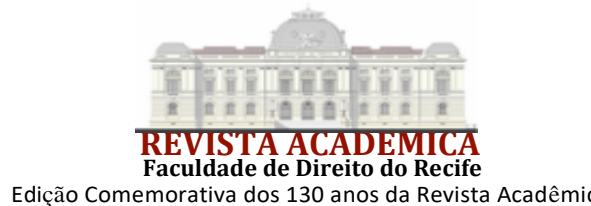

Edição Comemorativa dos 130 anos da Revista Acadêmica

a) reconhecer a mora legislativa inconstitucional do Congresso Nacional em relação à edição de lei criminalizadora quando decorrente de mandamento constitucional de criminalização para proibição de proteção insuficiente a direitos e garantias fundamentais;

b) fixar prazo razoável para a edição da referida lei que face à ausência de regulamentação deste pela Lei 9868/1999, poderia ser fixado em 12 meses, por analogia ao ADCT, art. $8^{\circ}, \S 3^{\circ}$;

c) findo o prazo, face à continuidade da omissão legislativa inconstitucional e em atividade legislativa atípica, o STF, de modo subsidiário, regulamentar e instituir a tipificação de delitos decorrentes de mandamentos constitucionais de criminalização, preferencialmente repetindo a posição adotada no julgamento dos MIs 670, 708 e 712 de utilizar a lei já existente (nesse caso, como foi feito na decisão da ADO 26 em relação à Lei 7716/1989) para a referida tipificação, reconhecendo ao Congresso Nacional, por óbvio, a qualquer tempo, a possibilidade de revogar a referida decisão com a edição de lei formal a respeito, com os efeitos subjacentes;

d) consequentemente, não proceder a uma regulamentação imediata da questão (Galindo: 2019).

Apesar desse alerta, não resta dúvida que o STF nesta importante decisão, utilizou da legalidade oblíqua e contramajoritária para defender o Estado laico, afastando a liberdade religiosa (ou mesmo de outra natureza) quando isso se configure discurso de ódio ou hostilidade direta e objetiva contra direitos e liberdades da população LGBTQIA+.

\section{CONCLUSÃO - O STF COMO GUARDIÃO DO ESTADO LAICO ATRAVÉS DA LEGALIDADE OBLÍQUA E CONTRAMAJORITÁRIA}

Tendo em vista as análises das páginas predecessoras, é possível enxergar na atuação do Supremo Tribunal Federal em muitas dessas questões uma postura proativa na construção de uma legalidade oblíqua, e por vezes contramajoritária, no que diz respeito à proteção de direitos fundamentais. Não raro o STF legisla obliquamente, institucionalizando uma espécie de rule of law que rivaliza com as leis provenientes do Congresso Nacional, com a diferença para o caso dos britânicos que, entre nós predomina a ideia de supremacia da Constituição, ao passo que no Reino Unido o tricentenário princípio da supremacia do parlamento ainda é consideravelmente forte.

É preciso que se diga que o parlamento é a casa legitimada diretamente pela população para fazer as leis e, em princípio, é lá que tais questões devem ser resolvidas, como tem sido em muitos lugares do mundo. Em países como Alemanha e EUA, questões consideradas "tabus" por aqui - como as que discutimos - foram resolvidas primordialmente pelo legislador (caso dos matrimônios homoafetivos nos EUA, p. ex. - cf. HOYO, 2007). Em outros casos, mesmo entre nós, o próprio Congresso Nacional decidiu, como na Lei de Biossegurança, e a atuação do STF apenas reforçou a decisão parlamentar. Mas na ausência/omissão do legislador ou mesmo em sua atuação ostensivamente contrária a direitos fundamentais de segmentos específicos da sociedade, os juízes constitucionais tendem à construção dessa legalidade oblíqua quando entendem necessário (caso específico dos tribunais constitucionais e das supremas cortes) e contrapõe formas de rule of law a possíveis autoritarismos majoritários.

No que diz respeito ao Estado laico, pode-se perceber que a legalidade oblíqua engendrada pelo STF tem sido direcionada ao fortalecimento da laicidade em detrimento da estatalização de perspectivas religiosas, quaisquer que sejam elas. A maioria dos Ministros do Tribunal ao se posicionarem a favor da constitucionalidade das pesquisas com células-tronco embrionárias e do aborto do anencéfalo, p. ex., buscaram respaldo científico para a decisão e rechaçaram os argumentos religiosos, ressaltando o caráter laico do Estado brasileiro. No caso da constitucionalidade das uniões estáveis homoafetivas e da criminalização da LGBTfobia, os 


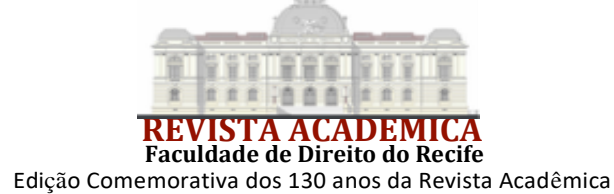

argumentos foram essencialmente jurídico-sociológicos, ainda que contrários à opinião da maioria (no primeiro caso) segundo pesquisas de opinião. No caso do direito à identidade de gênero, também se discutiu a partir das respostas científicas à questão da transexualidade. E em todos esses casos a perspectiva religiosa foi deixada de lado pela unanimidade dos Ministros, reforçando o princípio do Estado laico, ainda que pela via da legalidade oblíqua.

Ainda que isso enseje a controversa legalidade oblíqua e contramajoritária da qual falei e deva ser visto com cautelas, é fato que o STF tem se colocado nesses casos como efetivo guardião do Estado laico, o que, em última análise, antes de ser uma postura antirreligiosa, é essencialmente pró-liberdade religiosa, bem como de consciência e de crença. Ao não permitir que os argumentos estritamente religiosos guiem o debate político-jurídico da Corte, o STF em verdade protege todas as religiões, bem como as pessoas não religiosas, da obrigatoriedade de seguirem os dogmas de fé de uma religião específica. E a tolerância e o respeito recíprocos têm maior potencialidade de serem as regras de convívio social, deixando de lado imposições autoritárias a outrem de pontos de vista com os quais nem todos concordam.

\section{REFERÊNCIAS}

ACKERMAN, Bruce. A Nova Separação dos Poderes. Trad. Isabelle Maria Campos

Vasconcelos, Eliana Valadares Santos. Rio de Janeiro: Lumen Juris, 2009.

ADEODATO, João Maurício. Ética e Retórica: para uma Teoria da Dogmática Jurídica. 2. ed. São Paulo: Saraiva, 2006.

ARISTÓTELES. A Política. Trad. Roberto Leal Ferreira. 2. ed. São Paulo: Martins Fontes, 1998.

BLANCARTE, Roberto. O porquê de um Estado laico. In: LOREA, Roberto Arriada (org.). Em Defesa das Liberdades Laicas. Porto Alegre: Livraria do Advogado, 2008. p. 19-32.

BARNETT, Randy E. Restoring the Lost Constitution: the Presumption of Liberty. Princeton: University Press, 2004.

BAYON, Juan Carlos. Democracia y derechos: problemas de fundamentación del constitucionalismo. In: CARBONELL, Miguel; JARAMILLO, Leonardo García (org.). El canon neoconstitucional. Madrid: Trotta, 2010. p. 285-355.

BÍBLIA SAGRADA. Trad. João Ferreira de Almeida. São Paulo: Vida, 1996.

BONAVIDES, Paulo. Ciência Política. 10. ed. São Paulo: Malheiros, 2003.

BRITTO, Carlos Ayres. Teoria da Constituição. Rio de Janeiro: Forense, 2003.

CUNHA, Luiz Antonio. O ensino religioso na rede estadual do Rio de Janeiro: política e legislação. In: LOREA, Roberto Arriada (org.). Em Defesa das Liberdades Laicas. Porto Alegre: Livraria do Advogado, 2008. p. 173-188.

DIAS, Maria Berenice. A Justiça e a Laicidade. In: LOREA, Roberto Arriada (org.). Em Defesa das Liberdades Laicas. Porto Alegre: Livraria do Advogado, pp. 139-144, 2008.

DICEY, Albert Venn. Introduction to the Study of the Law of the Constitution. Indianapolis: Liberty Fund, 1982. 
DWORKIN, Ronald. O Império do Direito. Trad. Jefferson Luiz Camargo. São Paulo: Martins Fontes, 1999.

ECO, Umberto. O Cemitério de Praga. Trad. Joana Angélica D’Ávila Melo. Rio de Janeiro: Record, 2011.

FERNÁNDEZ-CORONADO, Ana. Matrimonio islámico, orden público y función promocional de los derechos fundamentales. Revista Española de Derecho Constitucional, Madrid, n. 85, p. 125-156, 2009.

FERRAJOLI, Luigi. Pasado y futuro del Estado de derecho. In: CARBONELL, Miguel (org.). Neoconstitucionalismo(s). Madrid: Trotta, 2003. p. 13-30.

GALINDO, Bruno. Criminalização da homofobia, omissões inconstitucionais e diálogos institucionais. Disponível em http://www.justificando.com/2019/02/25/criminalizacao-dahomofobia-omissoes-inconstitucionais-e-dialogos-institucionais/. Acesso em: 23 de nov. 2021.

GALINDO, Bruno. Princípio da legalidade oblíqua e súmula vinculante: a atuação legislativa da jurisdição constitucional nos 20 Anos da Constituição de 1988. In: BRANDÃO, Cláudio; CAVALCANTI, Francisco; ADEODATO, João Maurício (org.). Princípio da Legalidade: da Dogmática Jurídica à Teoria do Direito. Rio de Janeiro: Forense, 2009. p. 175-202.

GALINDO, Bruno. Teoria Intercultural da Constituição (a transformação paradigmática da Teoria da Constituição diante da integração interestatal na União Européia e no Mercosul). Porto Alegre: Livraria do Advogado, 2006.

GALINDO, Bruno. A teoria da constituição no common law: reflexões teóricas sobre o peculiar constitucionalismo britânico. Revista de Informação Legislativa, n. 164. Brasília, p. 303-316, 2004.

GARCÍA-PELAYO, Manuel. Derecho Constitucional Comparado. Madrid: Alianza, 1999.

HUACO, Marco. A laicidade como princípio constitucional do Estado laico. LOREA, Roberto Arriada (org.). Em Defesa das Liberdades Laicas. Porto Alegre: Livraria do Advogado, 2008. p. 33-80.

HOYO, Manuel Fernández del. Igualdad y due process substantivo en la reciente jurisprudência norteamericana sobre matrimonios del mismo sexo. Revista de Estudios Políticos, n. 138, p. 157$215,2007$.

JOWELL, Jeffrey. The Rule of Law Today. In: JOWELL, Jeffrey; OLIVIER, Dawn (org.). The Changing Constitution. 5. ed. Oxford: University Press, 2004. p. 1-25.

KRAMER, Larry D. The People Themselves: popular constitutionalism and judicial review. New York: Oxford University Press, 2004.

LIMA, Flávia Santiago. Jurisdição constitucional e política (ativismo e autocontenção no STF). Curitiba: Juruá, 2014. 


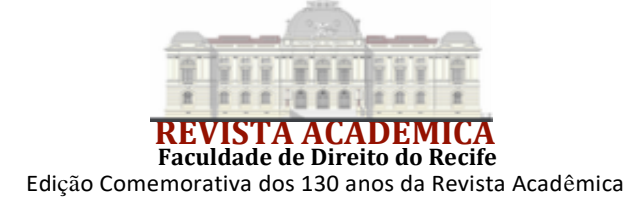

LOREA, Roberto Arriada. O assédio religioso. In: LOREA, Roberto Arriada (org.). Em Defesa das Liberdades Laicas. Porto Alegre: Livraria do Advogado, 2008. p. 159-172.

MACHADO, Maria das Dores Campos. A atuação dos evangélicos na política institucional e a ameaça às liberdades laicas no Brasil. In: LOREA, Roberto Arriada (org.). Em Defesa das Liberdades Laicas. Porto Alegre: Livraria do Advogado, 2008. p. 145-158.

MARTÍN VIDA, María Ángeles; MÜLLER-GRUNE, Sven “¿Puede una maestra portar durante las clases en una escuela pública un pañuelo en la cabeza por motivos religiosos? (Comentario a la Sentencia del Tribunal Constitucional Federal Alemán de 24 de septiembre de 2003, caso Ludin). Revista Española de Derecho Constitucional, Madrid, n. 70, p. 313-337.

MENDES, Gilmar. Estado de Direito e Jurisdição Constitucional 2002-2010. São Paulo: Saraiva, 2011.

NEVES, Marcelo. Entre Têmis e Leviatã: uma relação difícil. São Paulo: Martins Fontes, 2006.

NEVES, Marcelo. A Interpretação Jurídica no Estado Democrático de Direito. In: DIREITO CONSTITUCIONAL: Estudos em Homenagem a Paulo Bonavides. São Paulo: Malheiros, 2001. p. 356-376.

NUÑEZ LADEVÉZZ, Luis. Identidad democrática y libertad religiosa. Revista de Estudios Políticos, Madrid, n. 137, p. 37-66, 2007.

OLIVEIRA JR., Pe. Guaraciba Lopes de. Células-tronco embrionárias humanas: salvar uma vida justifica destruir outra? Disponível em: https://www.cnbb.org.br/celulas-troncoembrionarias-humanas-salvar-uma-vida-justifica-destruir-outra/. Acesso em: 12 nov. 2021.

ORO, Ari Pedro. A laicidade na América Latina: uma apreciação antropológica. In: LOREA, Roberto Arriada (org.). Em Defesa das Liberdades Laicas. Porto Alegre: Livraria do Advogado, 2008. p. 81-96.

ORTEGA, Abraham Barrero. Libertad religiosa y deber de garantizar la vida del hijo (a proposito de la STC 154/2002, de 18 de julio). Revista Española de Derecho Constitucional, Madrid, n. 75, p. 325-356, 2005.

RAWLS, John. El Liberalismo Político. Trad. Antoni Domènech. Barcelona: Crítica, 2004.

RIBEIRO, Ricardo Silveira. Política Constitucional no Supremo Tribunal Federal: uma Análise Quantitativa do Processo Decisório nas Ações Diretas de Inconstitucionalidade (1999-2004), 2007. Tese (Doutorado) - Universidade Federal de Pernambuco, Recife, 2007.

ROUSSEAU, Jean-Jacques. O Contrato Social e Outros Escritos. Trad. Rolando Roque da Silva. São Paulo: Cultrix, 1995.

SABAU, José Ramón Polo. En torno a la naturaliza jurídica de la libertad ideológica y religiosa en la Constitución española. Revista de Estudios Políticos, Madrid, n. 129, p. 137-162, 2005.

SALDANHA, Nelson. Formação da Teoria Constitucional. 2. ed. Rio de Janeiro: Renovar, 2000. 
SANTORO, Emilio. Rule of law e "liberdade dos ingleses". A interpretação de Albert Venn Dicey. Trad. Carlos Alberto Dastoli. In: COSTA, Pietro; ZOLO, Danilo (org.). O Estado de Direito: História, Teoria, Crítica. São Paulo: Martins Fontes, 2006. p. 201-263.

SIEYÈS, Emmanuel Joseph. A Constituinte Burguesa-Qu'est-ce que le Tiers État? Trad. Norma Azeredo. 3. ed. Rio de Janeiro: Lumen Juris, 1997.

TRIBE, Laurence H. American Constitutional Law. 13. ed. New York: Foundation Press, 2000. V. 1 .

VALLE, Vanice Regina Lírio do (org.). Ativismo Jurisdicional e o Supremo Tribunal Federal (Laboratório de Análise Jurisprudencial do STF). Curitiba: Juruá, 2009.

VÁSQUEZ, Rodolfo. Justicia constitucional y democracia: la independência judicial y el argumento contramayoritario. In: CARBONELL, Miguel; GARCÍA JARAMILLO, Leonardo (org.). El canon neoconstitucional. Madrid: Trotta, 2010. p. 381-402. 